\title{
IMPORTANCE OF MARKETING COMUNICATION TOOLS WITH REGARDS TO THE COMPETITIVENESS OF MINI-BREWERIES
}

\author{
Monika B̌̌EZINOVÁa ${ }^{\mathrm{a}}$, Ladislav SKǑ̌EPA ${ }^{\mathrm{a}}$ \\ a University of South Bohemia, Faculty of Agriculture, Studentská 1668, 37005 České Budějovice, Czech \\ Republic.
}

Cite this article: Březinová, M., Skořepa, L. (2019). Importance of Marketing Comunication Tools with regards to the Competitiveness of Mini-Breweries. Deturope, 11(1), 149-163.

\begin{abstract}
In accordance with the general world trend, a new form of breweries expands in the Czech beer market mini-breweries. More than 220 new mini- breweries have been established in the period 2013-2016. This tendency does not let up. As the number of mini-breweries increases, we can inspect a strengthening competing pressure in this sector. Mini-breweries are supposed to start to really compete within among themselves and fight for customers. The data collection was done in January 2017 by means of an electronic survey on all population of mini-breweries (350 companies registered by December 31, 2017). The response rate was $41 \%$. The aim of the paper is, by means of the descriptive statistics methods, to find out, what marketing tools the small breweries' managers or proprietors consider as most important with regards to the competitiveness of their business. The collected data were analysed by means of one-way classification according to the defined segmentation criteria. Most of respondents consider a good reputation (89\%), recommendation of current clients $(85 \%)$, and own website $(60 \%)$ to be most important communication tools.
\end{abstract}

Keywords: mini-brewery, local, marketing, communication, promotion

\section{INTRODUCTION}

In present days, the Czech beer market experience establishing of a new form of breweries mini-breweries. The increase of the number very strong in recent years not only in the Czech Republic (Theuvsen, 2005; Ellis \& Bosworth, 2015; Colen, 2016; Chlebicka, Fałkowski, \& Lichota, 2018). Emerging mini-breweries represent an important factor of the economic development of regions or even rural areas (Ellis \& Bosworth, 2015) and of their business activity. By the end of 2016, 350 mini-breweries operated in the Czech Republic, and some of them have already firmly established, with a progressively increasing volume of the beer produced and number of staff and they are extending their activity. Other mini-breweries do not intend and seek to increase their production even because of their short existence or due to their initial objective. Researchers show two main reasons for establishing a mini-brewery (Cabras, 2016). The first reason is a pure enthusiasm for bear and an intention to brew a beer according to meet requirements of themselves for taste and quality. The latter are particularly 
caused by a volume of undesirable matters in beer. According to Belakova (2017), undesirable matters were revealed in $83 \%$ of beer samples from retail shops in the Czech Republic. The volume of such matters was inconsiderable, nevertheless. The second reason is a business plan. Similarly to other quickly growing markets (of more than $10 \%$ annually), the mini-brewery market is attractive for many investors, who observe an important boom in this sector. The paper deals with a perceived importance of marketing tools by proprietors or managers, in connection with building a market position and competing for clients.

\section{THEORETICAL BACKGROUNDS}

Small and middle enterprises play a strong role in world economy (Beck, Demirguc-Kunt, \& Levine, 2005; Lukács, 2005) and so they do in case of a regional economy and regional development. They are considered an important engine for economic growth in terms of both employment and gross domestic product (Bocconcelli et al., 2018).

Marketing communication is a term used to encompass every aspect of the visual, written, spoken or sensory interaction between a business and its market or markets (Cooper and Lane, 1997: 133)

It is mostly about a commercial communication, the objective of which is, based on the transmitted information, to influence cognitive, motivational and decision-making processes of those who we should address in accordance with our intentions (Vysekalová \& Komárková, 2002)

Marketing communication in SMEs has its limitations issuing from the size of the enterprise and consequently from problems, such a lack of budget or lack of human resoursces. Some theories (Schmid, 2014) mention also limited information sources and experience.

Several theoretical bases could be used to systemize marketing communication techniques and tools, for instance a part of 4P as adopted by Kotler (2003) - communication mix - that in his conception comprises advertising, direct marketing, personal selling, public relations and sales promotion. Another is approach is represented by De Pelsmacker's (2001) marketing communication tools - advertising, sales promotion, sponsorship, public relations, personal selling, direct marketing, point-of-purchase communications, exhibitions and fairs and internet.

All the above-mentioned techniques and tools are used in the brewery industry. Their employment depends always on the particular situation. One of the most important factors that influence constitution of the communication mix is the size of the brewery, or more precisely its financial power, then specifics of the administered segment of customers (Castilione, 2011). 
From that point of view, we can distinguish a mass marketing communication that use mass communication tools and focus as big number of potential customers as possible. It is used by large industrial breweries. A targeted marketing communication use personal communication channels and focus a particular group of customers. This marketing communication serves to mini-breweries (Kotler, 2003). Industrial breweries that realize an expensive TV-advertisement lived a decrease of the volume of beer produced of 5\% in 2015 and then again of $10 \%$ in 2016 (the expansion of mini-breweries could be a reason of this situation). On the contrary, some regional breweries decreased considerably their budget for a classic communication and yet they increased their volume of beer produced. For instance, the brewery Svijany used the wordof-mouth method and it increased its volume of beer produced twofold in 2013 (Kozák, 2014).

Mini-breweries are newcomers in the Czech beer market and they communicate with their customers particularly through their product - beer. Their main assets are uniqueness and localness (Toro, 2014). The word-of-mouth communications predominates in their promotion, and the information spreads thanks to satisfied visitors to breweries and funs of unconventional beers (Stoklasek, 2013) spread it. This phenomenon has an overlap - similarly to the wine tourism - the beer tourism (Duda, 2013; Kraftchick, 2014). A number of mini-breweries provide accommodation and catering services (Kozák, Bartók, \& Honzková, 2017). and help thus strengthen tourism in the area and then further support local economies.

As already mentioned above, the most important factor influencing the mini-breweries' choice of marketing tools, is their budget (George, 2013). This is why mini-breweries mostly do not use the mass communication tools and channels (such expenditures would be very probably inefficient considering the target groups of customers). They use, however, personal, targeted marketing channels, such as regional press, social media or other more appropriate and less expensive ways to address regional or even local markets.

A very common approach also is to become a member in organisations that associate minibreweries, for instance Association of small breweries, Club of small breweries, CzechMoravian union of mini-breweries, etc. These associations organize common meetings and events through which they spread awareness of small breweries among potential customers and contribute this way to increasing customers' interest in the products of small breweries (Kozák, 2013).

Products of mini-breweries could mostly be considered as local or regional product. They usually influence local economy within their action radius, using local source (particularly manpower, but also some materials or ingredients), so they could be considered as an activation 
of indigenous resources that can be a take-off point of long-term development (Káposzta, Ritter, \& Kassa, 2015). Their production could also issue from local traditional procedures, to respond to the local taste specifics of consumers or else to contribute to the sense of belonging of inhabitants, and to strengthen their relation to their place of living, which was a longterm phenomenon in the traditional beer regions (which the Czech Republic historically is). Thus the small breweries could satisfy the recently increasing consumer demand for local products. The emergence of the boom of mini-breweries is then also encompassed with global trends - the search for "local” (Chlebicka, Fałkowski, \& Lichota, 2018; Nezdei, \& Alpek, 2018; Pícha, \& Skořepa, 2018). "Localness" should be communicated by means of the surveyed tools as it could be a strengthening element when attracting consumers (Pícha, Skořepa, \& Navrátil, 2013; Pícha, Navrátil, \& Švec, 2018). The aim of the paper is, by means of the descriptive statistics methods, to find out, what marketing tools the small breweries' managers or proprietors consider as most important with regards to the competitiveness of their business.

\section{Hypotheses}

Hypothesis 1: minibreweries use rather money-extensive communication tools

Hypothesis 2: minibreweries put the main emphasis on local media in their marketing communications

\section{METHODS}

\section{Data collection}

Method of electronic questionnaire survey was adopted to collect the data. The survey took place in January 2017. We addressed all population (350 mini-breweries), i.e. all minibreweries that were registred at that moment in the Czech Republic. The response rate was $41 \%$ (145 mini-breweries). The geographical structure of the surveyed sample could be seen at the Fig. 1).

Figure 1 Geographical structure of surveyed mini-breweries 


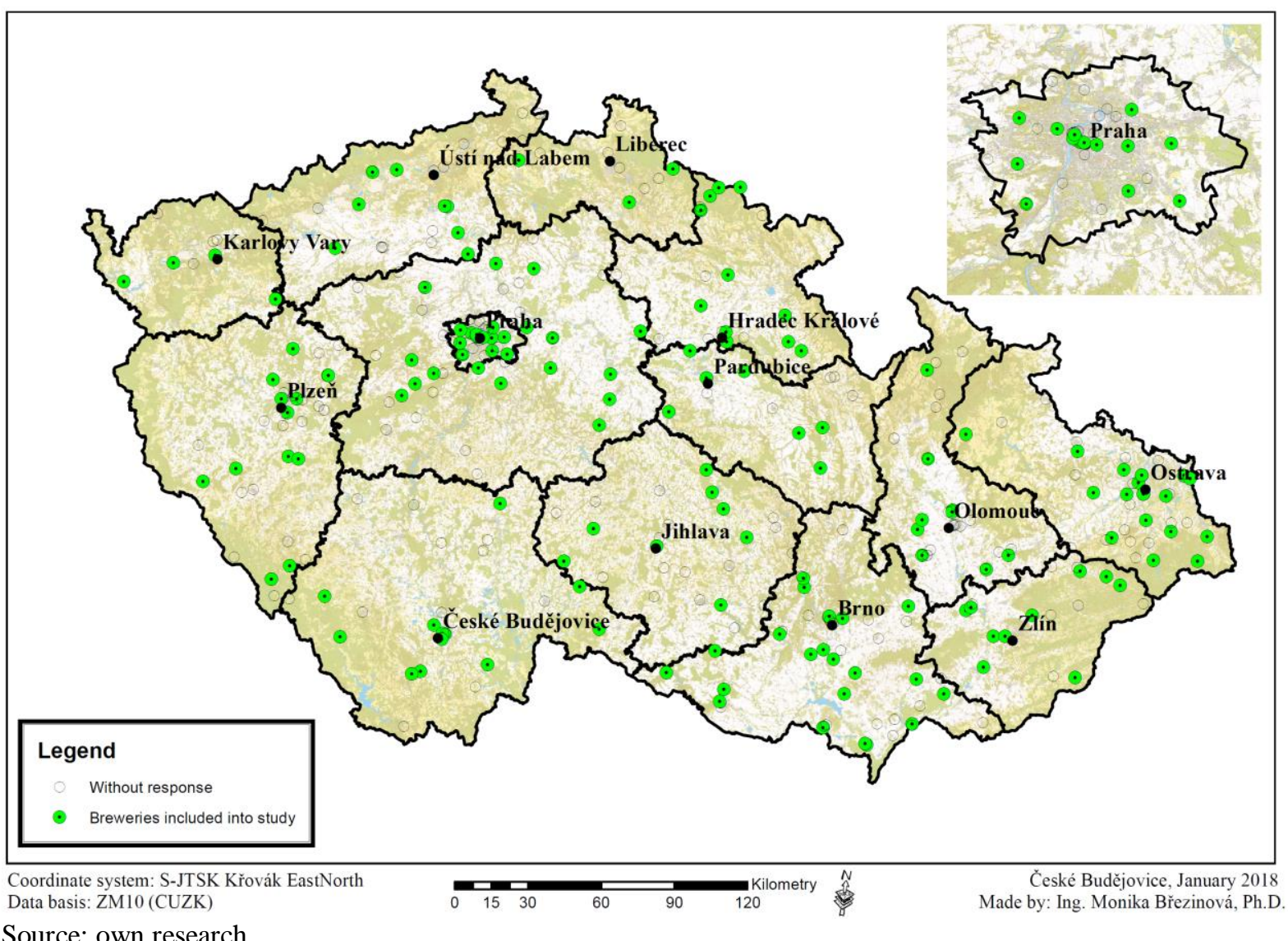

Source: own research

\section{Data analysis}

Descriptive statistical methods were used to analyse the collected data - absolute frequency and contingency tables. The results are presented by means of graphs and tables. The particular results were assessed according to the following segmentation criteria - year of company formation, location (inside of the town, at the periphery of the town, out of the town) and existence of the own restaurant or pub.

\section{Results and discussion}

Fig. 2 shows the proprietors' evaluation of particular marketing communiction tools in relation to the competitiveness of their mini-breweries. The proprietors perceive a good name/reputation of the brewery as most important (89\%); the second most important is a recommendation of existing customers ( $85 \%$ ) that is spread through word-of-mouth (WoM). The WoM technique do not require any costs to disseminate information - it is based on a quality product that costumers recommend among themselves. Further important marketing communication tools are social networks $(53 \%)$ and their own website $(60 \%)$ that represent other "low-cost" tools. They are followed by drinking glasses (39\%), labels (42\%) and brewery signs or restaurant signs (34\%). These tools that help to identify the product are indispensable in the brewery sector. Another identified important factor are excursions (32\%) that aim for one 
thing to get visitors acquainted with the production in the particular brewery, with ingredients, with the types of beers and for another thing of course to offer the possibility to taste the beers. Taste and testing are an important element of so called sensory marketing (Géci, Nagyová, \& Rybanská, 2017). Generally, we can conclude that proprietors do not perceive the marketing communication tools as strongly important for their competitiveness in the contrast to the quality and taste of the product. The exception is the good name of the brewery and recommendation of existing customers that are perceived as important by $90 \%$ of surveyed breweries.

Figure 2 Importance of marketing communication tools in relation to the competitiveness of the brewery

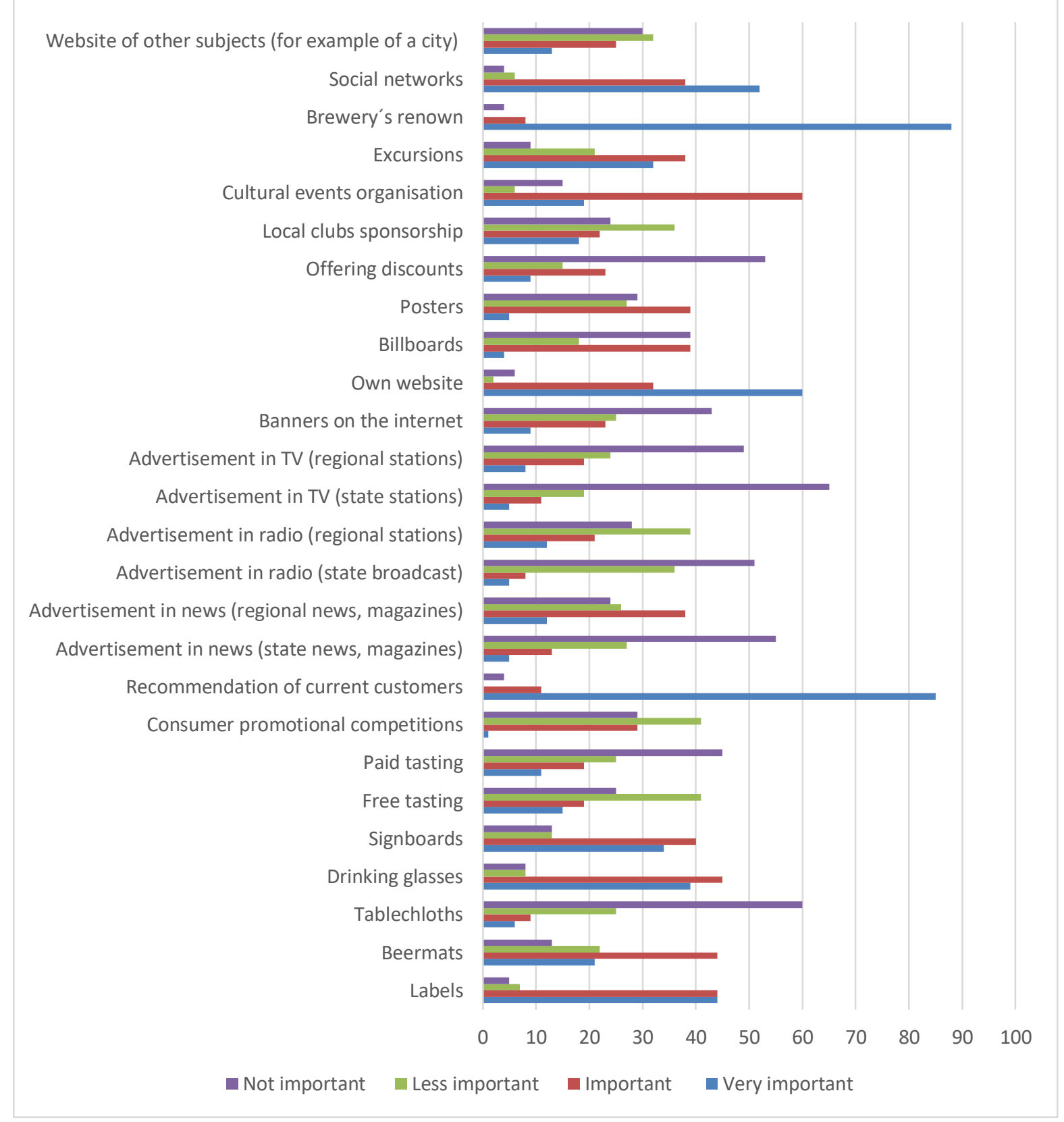

Source: own research 
Further results according to the segmentation criteria are presented in subsequent parts of the paper in fig. 3 to 9. The answers "not important" and "less important" were grouped and so were even the items "important" and "very important".

Figure 3 Importance of particular marketing communication tools for mini-breweries with their own restaurant or pub

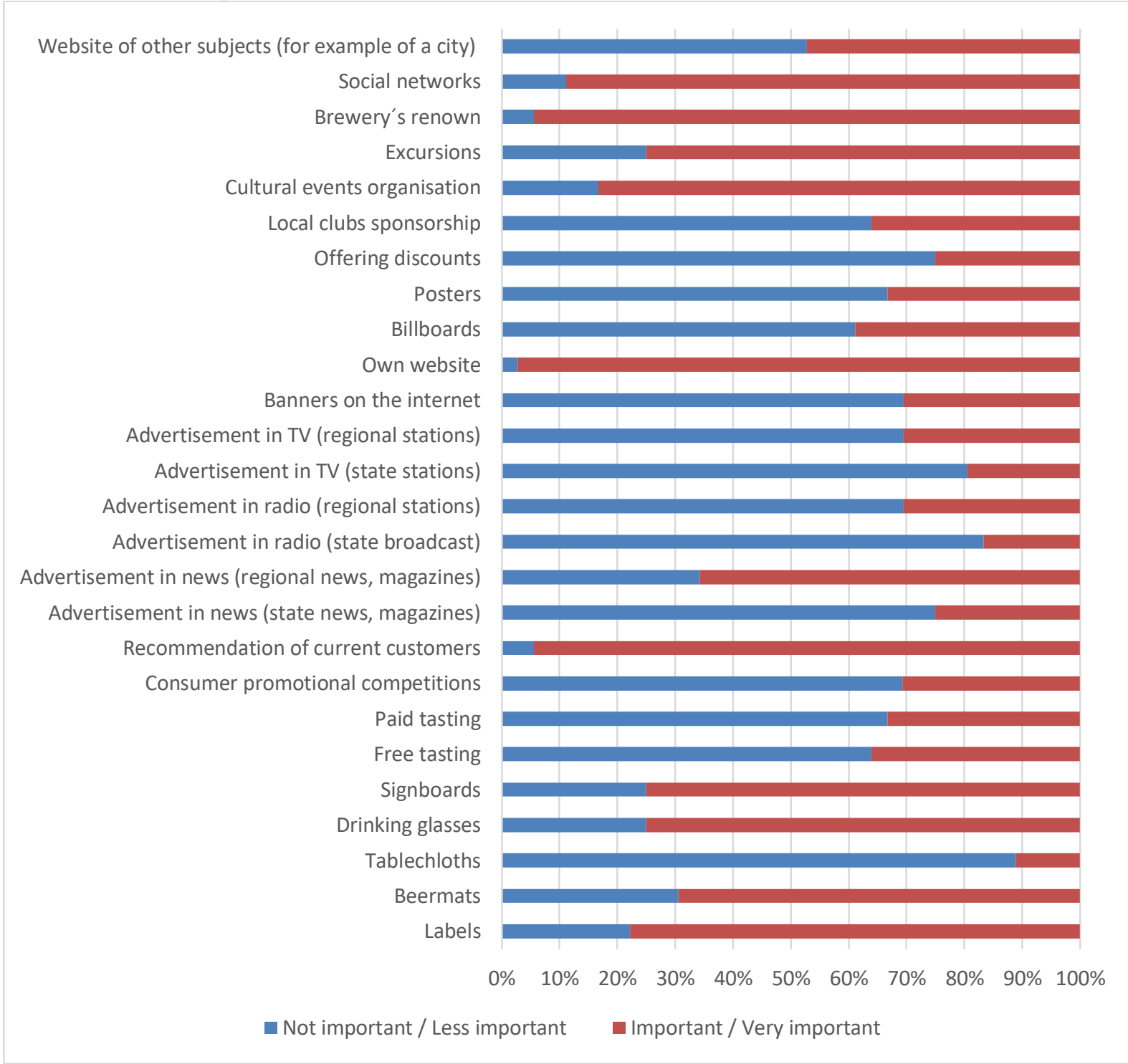

Source: own research

We have identified no important differences in perception of importance of particular marketing communication tools for breweries' competitiveness according to the existence of their own restaurant/pub. Fig. 3 and 4 show that there are no significant differences between perception of importance of marketing communication tools by proprietors of mini-breweries with their own restaurant and without their own restaurant, even in case of those tools were we have supposed substantial differences, such as drinking glasses or table cloths. Drinking glasses are important or very important for $75 \%$ breweries with their own restaurant and for $82 \%$ breweries 
without their own restaurant; table cloths are important or very important for $11 \%$ breweries with their own restaurant and for $25 \%$ breweries without their own restaurant. The higher importance for breweries without their own restaurant is surprising. We can assume that those tools serve in this case as presents or promotional items. The assumption was confirmed in case of importance of beermats $(70 \%$ for breweries with their own restaurant, whereas $31 \%$ for breweries without their own restaurant). Even in this case the breweries without their own restaurant probably use the tool as a promotional item or a present, particularly for collectors.

Figure 4 Importance of particular marketing communication tools for mini-breweries without their own restaurant or pub

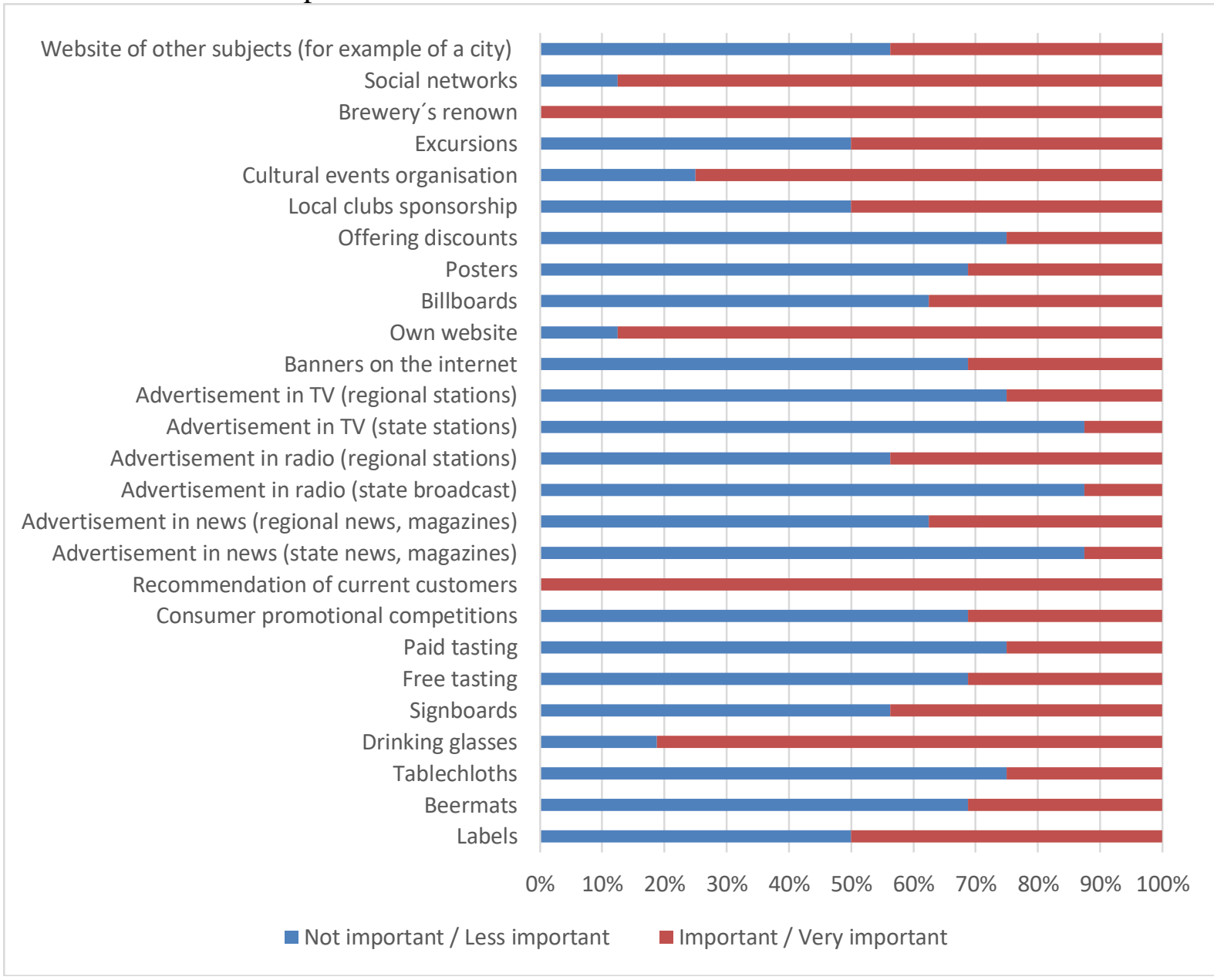

Source: own research

Further, we have found significant differences in perception of the importance of particular marketing communication tools according to the duration of the company. All mini-breweries that came into existence before the year 2000 perceive the importance or even strong importance of social networks, good name of the brewery, excursions, cultural events, their own website, recommendation of existing customers, drinking glasses and labels (Fig. 5). 75\% of those breweries have mentioned sponsorship, posters, paid degustation, brewery signs or 
restaurant signs, and beermats. In case of the mini-breweries originating before the year 2000, there is no marketing communication tool that is not important for at least $25 \%$ of them. 21 out of 26 surveyed marketing tools are important or very important for at least $50 \%$ of this group of breweries.

Figure 5 Importance of particular marketing communication tools for mini-breweries operating already before the year 2000

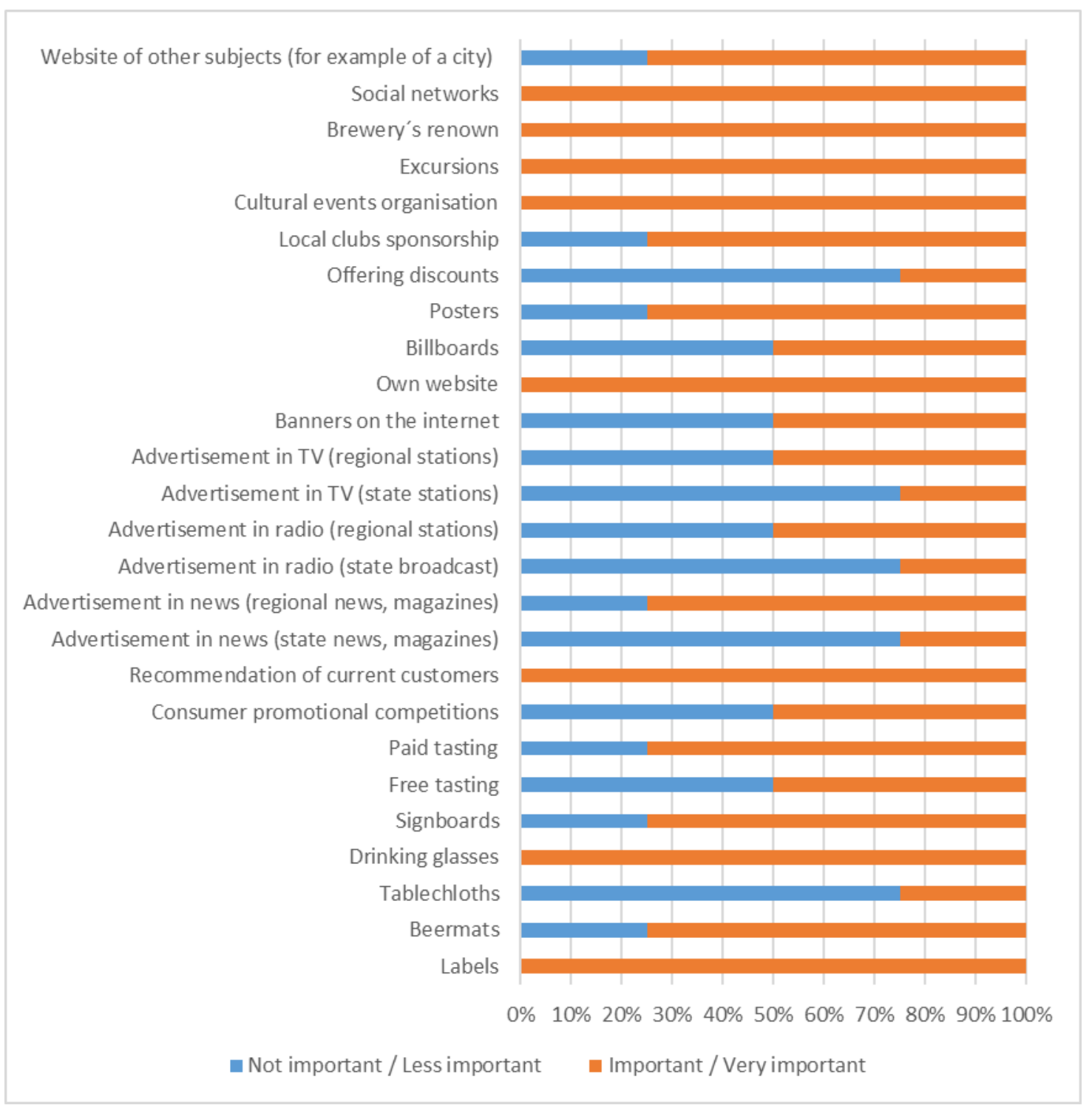

Source: own research

Good name of the brewery, recommendation from current customers and labels are important or very important for $100 \%$ of mini-breweries that were established from 2001 to 2010 (Fig. 6). Social networks and cultural events are important for $90 \%$ of them; their own website is important for $80 \%$ of this group, excursions only for $40 \%$ and sponsorship only for $20 \%$ of 
these mini-breweries. On the other hand, billboards and tablecloths are perceived as not important at all.

Figure 6 Importance of particular marketing communication tools for mini-breweries established in the period from 2001 to 2010

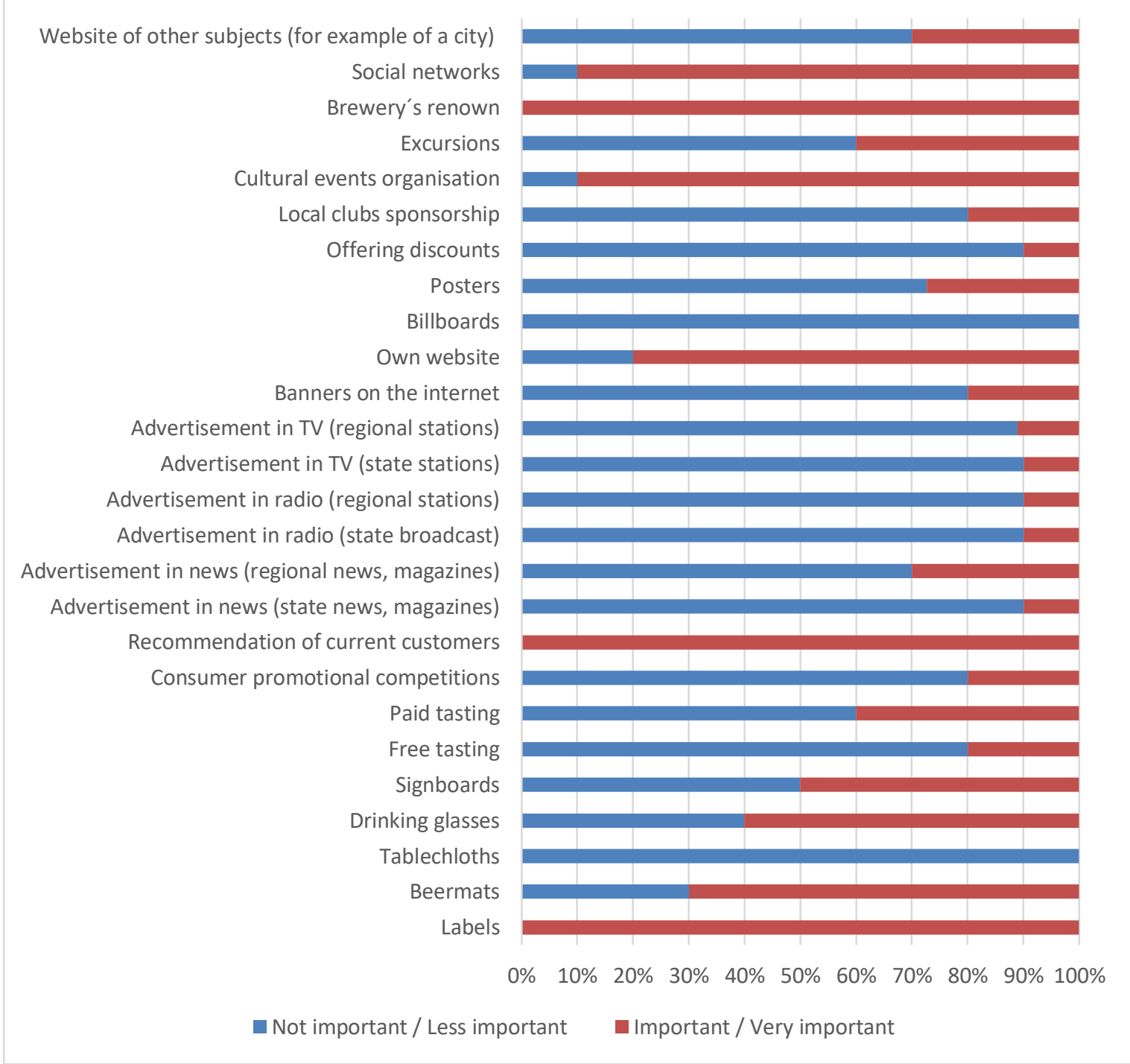

Source: own research

As for the last groups of surveyed breweries, more than $70 \%$ of them perceive as important or very important following marketing communication tools: social networks, good name of the brewery, excursions, organizing of cultural events, their own websites, recommendation from current customers, drinking glasses and labels. The perceptions and opinions of this third group of respondents is somehow in between the first two groups. The second group - breweries issued from the period 2001-2010 - perceives the least number of marketing and tools as important or very important, whereas the first group - breweries that came into existence before 
the year 2000 found most of the marketing communications tools as important or very important.

Figure 7 Importance of particular marketing communication tools for mini-breweries established in the period from 2011 to 2016

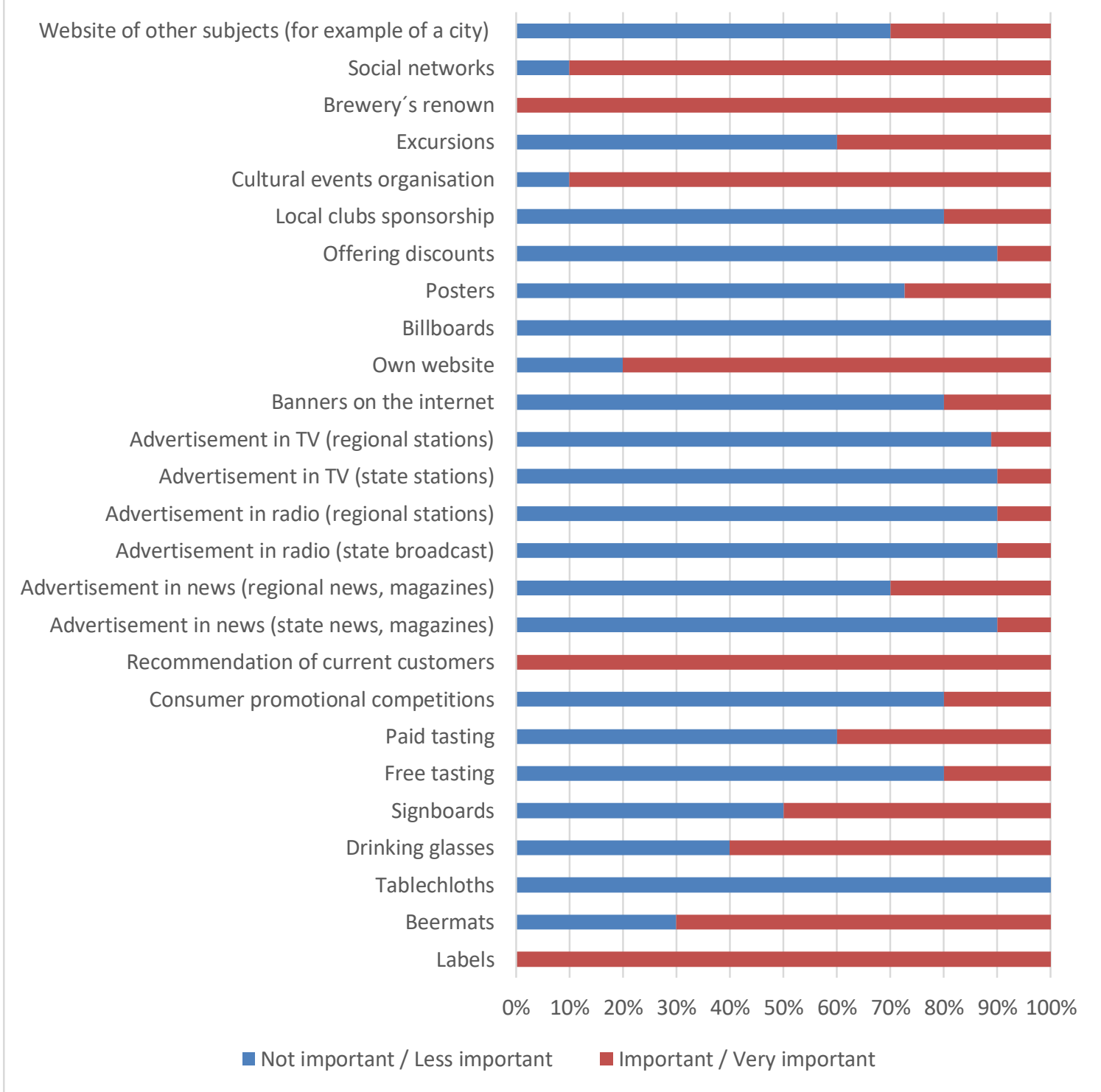

Source: own research

For reasons of clarity, we have divided the surveyed breweries into two groups according to the place of operation of the breweries (Fig. 8). First group comprises mini-breweries located in the center or in the periphery of towns and the second group represents mini-breweries located out of the towns. Presented results were also merged from four to two groups of answers (not important and less important vs. Important and very important). 
Figure 8 Importance of particular marketing communication tools for mini-breweries located in the center or in the periphery of the towns

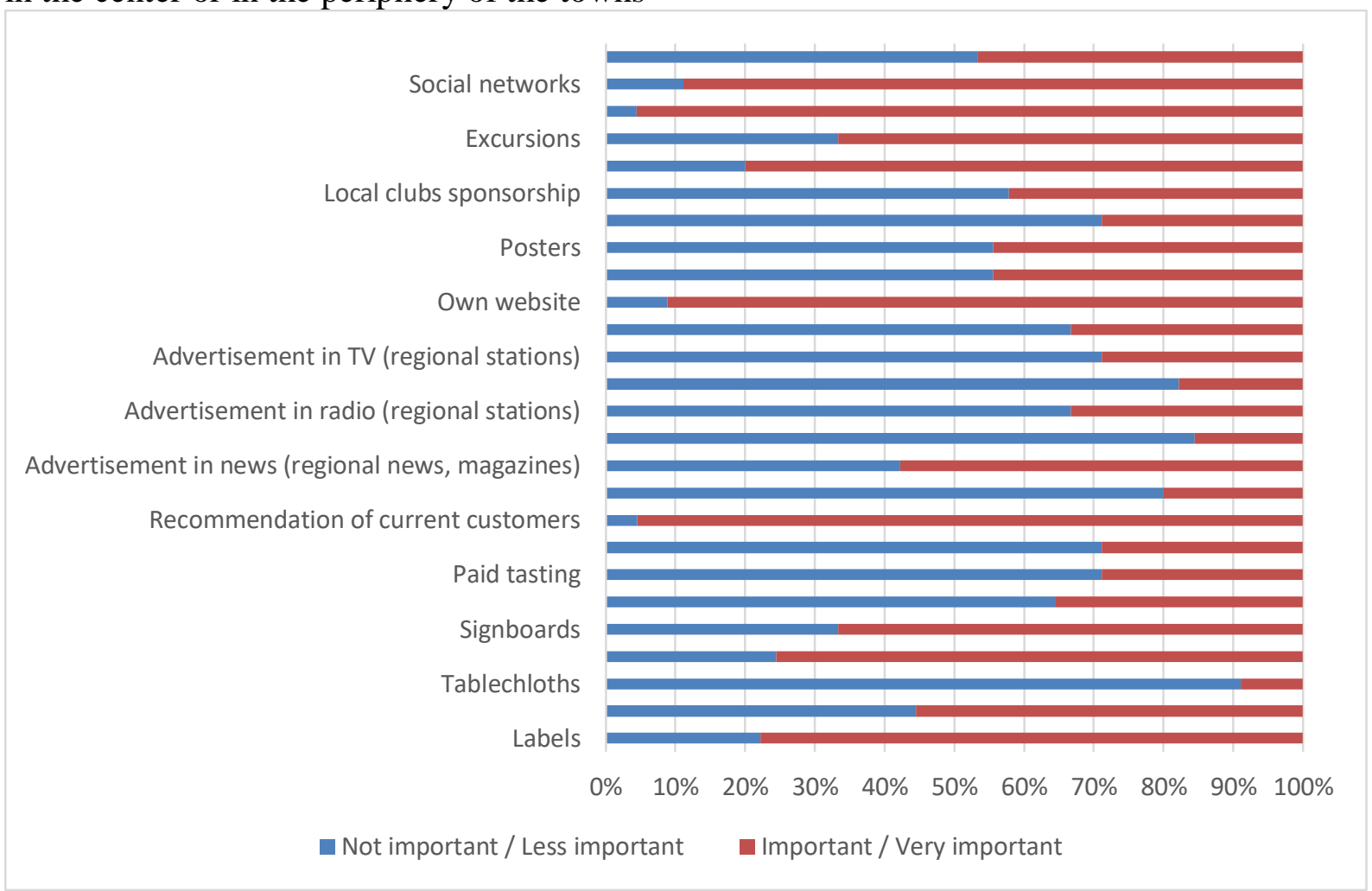

Source: own research

The most significant differences in the perception of importance of particular marketing communication tools occurred in case of offering discounts. This tool is very important or important for $30 \%$ of mini-breweries located in the center or periphery of the towns but less important or unimportant for all (100\% mini-breweries located out of the towns and villages (Fig. 8, Fig. 9). Another tools with differently perceived importance was billboard that is unimportant for $55 \%$ of mini-breweries located in the center or in the periphery of the towns, but for all (100\%) mini-breweries located out of the towns. On the other hand, own website is important for almost all mini-breweries $-100 \%$ of mini-breweries located out of the town and $90 \%$ mini-breweries located in the center or in the periphery of the towns.

Regional/local radios are also important for a considerable number of mini-breweries located out of the town (60\%) compared to the group of mini-breweries in the town centers and peripheries $(35 \%)$. On the contrary, regional/local press is important for a more of minibreweries in the town centers and peripheries (58\%) then breweries out of the town (40\%). Offering discounts, billboards, regional press and tablecloths are generally more important for breweries located in town center or town periphery (Fig. 8) whereas good name of the brewery, own website, regional radios, national press, recommendation from current customers, paid degustations and beermats are important for majority of breweries located of the town (Fig. 9). 
Figure 9 Importance of particular marketing communication tools for mini-breweries located out of the towns or villages

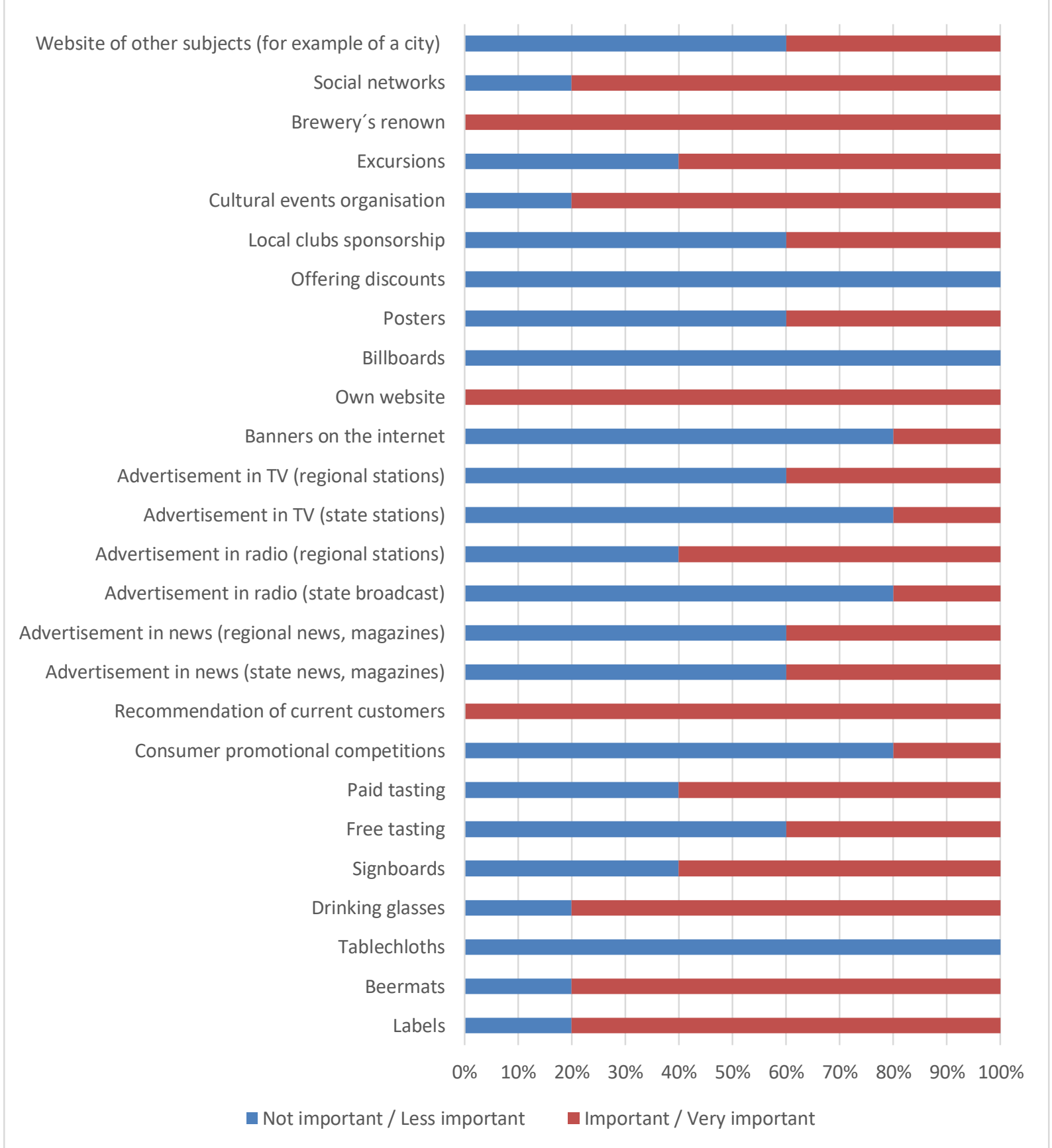

Source: own research

\section{CONCLUSIONS}

We can confirm that the small breweries prefer the money-extensive communication tools, like support to a positive word of mouth or their own websites. On the other hand, we cannot confirm our presumptions that they will, as a local player, put more emphasis on local media compared to national media. Observing the development in the beer industry and especially in the segment of mini-breweries, we can assume that the competitive pressure will continue to grow. Owners of mini-breweries will be supposed to spend more money for promotion, if they want to 
maintain or even increase the volume of beer produced. We can anticipate it at least based on the incredible increase of the number of mini-breweries in the Czech Republic in last two or three years. Given the financial possibilities of microbreweries, it is necessary to choose marketing tools that are meaningful and bring the effect of the money spent, whether in the form of greater turnover or profit. The most important factor will still be the quality and taste of the product itself, and in this context, the marketing tools that are most often used by microbreweries and are important or very important to microbreweries in terms of their competitiveness, as demonstrated by the presented. Tools that can be recommended on this basis are: microbrewery referrals and microbrewery reputation (WoM), internet-based microbrewery presentations, social networking and custom websites, on-site marketing tools, glasses, labels and mats. However, precisely in the period of increasing of competitive pressure in microbreweries, it will be necessary to support these tools by others, which are not currently important for microbreweries and are not used as abundantly as previous ones. Microbrewery owners should consider using local media, such as local radio and television stations, as well as presenting the brewery on websites of other entities such as the city where the microbrewery has its headquarters, sports and other local organizations and, last but not least, microbreweries (valid only for microbreweries with their own restaurant) should pick up the function of cultural centers of municipalities where joint actions of local citizens will be realized. Future research activity could focus the potential of mini-breweries or micro-breweries with their own restaurant to attract consumers by trying to play a role of a cultural center, especially in rural areas.

\section{REFERENCES}

Beck, T., Demirguc-Kunt, A., \& Levine, R. (2005). SMEs, growth, and poverty: cross-country evidence. Journal of economic growth, 10(3), 199-229.

Beláková, S., Wawroszova, S., Benešová, K. (2017). The Occurrence of Mycotoxins in Beers from Retail Shops. Kvasný průmysl. 63(6), 293-297.

Bocconcelli, R., Cioppi, M., Fortezza, F., Francioni, B., Pagano, A., Savelli, E., \& Splendiani, S. (2018). SMEs and marketing: a systematic literature review. International Journal of Management Reviews, 20(2), 227-254.

Cabras, I. (2016). Beer, brewing, and business history. Business History. 58(5), 609-624.

Castilione, C., \& Grochová, L. (2011). The demand for beer in the view of past consumption and advertising in the Czech Republic. Agric.-econ.-Czech. 57(12), 2011, 589-599.

Chlebicka, A., Fałkowski, J., \& Lichota, J. (2018). From Macro to Micro: The Change of Trendsetters in the Polish Beer Market. In Economic Perspectives on Craft Beer. Cham, Palgrave Macmillan. 295-319.

Cooper, J., \& Lane, P. (1999). Marketingové plánování - praktická příručka manažera. Praha: Grada Publishing, 1999. 
Colen, L. (2016). Economic Growth, Globalisation and Beer Consumption. Journal of Agricultural Economics. 67(1), 186-207.

Cortese, D. (2017). The art of craft beer in a traditional wine nation: A preliminary study in a model area(Article). Quality - Access to Success. 18(161), 149-156.

De Pelsmacker, P., Geuens, M., \& Van den Bergh, J. (2001). Marketing communications. Financial Times/Prentice Hall.

Duda-Gromada, K. (2013). Beer tourism in Poland, Prace i Studia Geograficzne, 52, 63-84.

Ellis, V., \& Bosworth, G. (2015). Supporting rural entrepreneurship in the UK microbrewery sector. British Food Journal, 117(11), 2724-2738.

Géci, A., Nagyová, L., \& Rybanská, J. (2017). Impact of sensory marketing on consumer' s buying behaviour. Potravinarstvo Slovak Journal of Food Sciences, 11(1), 709-117.

George, L. M. (2013). National television and the market for local producz: The case of beer. Journal of industrial economics. 57(1), 85-111.

Káposzta, J, Ritter, K. \& Kassa, Z. (2015). Examination of the territorial significance of Pálinka as a Hungaricum. Tér és Társadalom, 29(4), 139-153

Kotler, P., Amstrong, G. (2003). Marketing, 6. vydání, Grada, 2003.

Kozák, V., Bartók, O., \& Honzková, I. (2017). Application of Destination Management for Rožnov Brewery and Rožnov Beer Spa Productivity Increase. ICFE 2017 - The $4^{\text {th }}$ International Conference on Finance and Economics, 376-384.

Kozák, V., Kozáková, V. (2013). Změny v českém pivovarství na prelomu tisíciletí. Zlín: VeRBuM.

Kozák, V., Kozáková V. (2014). Televizní reklamy českých pivovarů a jejich vnímání. Zlín: VeRBuM.

Kraftchick, J.F. (2014). Understanding beer tourist motivation. Tourism Management Perspectives. 12, 41-47.

Lukács, E. (2005). The economic role of SMEs in world economy, especially in Europe. European integration studies, 4(1), 3-12.

Pelsmacker, P. de, Geuens, M., Van der Bergh, J. (2003) Marketingová komunikace. Grada Publishing a.s., 2003

Nezdei, C., \& Alpek, B. L. (2018). Examining customer groups through the example of Balaton Resort Area marketplaces. TER ES TARSADALOM, 32(1), 145-160.

Pícha, K., Navrátil, J., \& Śvec, R. (2018). Preference to local food vs. Preference to "national" and regional food. Journal of Food Products Marketing, 24(2), 125-145.

Pícha, K., \& Skořepa, L. (2018). Preference to Food with a Regional Brand. Calitatea, 19(162), 134-139.

Pícha, K., Skořepa, L., \& Navrátil, J. (2013). Assessment of the results of the strategic orientation on regional and local products in food retail. Acta universitatis agriculturae et silviculturae Mendelianae Brunensis, 61(4), 1061-1068.

Schmid, S. (2014). The Global Brewery Industry. Markets, Strategies, and Rivalries Journal of International Management, 20(4), 478-480,

Theuvsen, L. (2005). Electronic Commerce Readiness in the Food Industry: Development and Application of an Assessment Tool. In Proceedings of the EFITA/WCCA 2005 Joint Conference. Vila Real (pp. 559-566).

Toro-Gonzáles, D. (2014). Beer snobs do exist: Estimation of beer demand by type, Journal of Agricultural and Resource Economics, 39(2), 174-187.

Vysekalová, J., \& Komárková, R. (2002). Psychologie reklamy: 2. rozšířené a aktualizované vydání, Praha: Grada Publishing. 